\title{
RECENT PROGRESS IN THE METALLURGY OF COPPER.*
}

\author{
BY \\ HEINRICH O. HOFMAN, E.M., Met.E., Ph.D., \\ Professor of Metallurgy, Massachusetts Institute of Technology, Boston, Mass.
}

\section{INTRODUCTION.}

THE aim of all smelting of stlphide copper ore is to collect the copper in matte which contains usually 40 to 45 per cent. $\mathrm{Cu}$, 35 to 30 per cent. $\mathrm{Fe}$, and 25 per cent. S, and the missing constituents in a slag, a mixture of silicates of iron, lime, etc., low enough in $\mathrm{Cu}$ to form a waste product. The iron and sulphur of the matte are separated from the copper by the converter process. This furnishes a crude copper and slag which is too rich in copper to be discarded, and goes back into the ore-smelting; the crude copper is subjected to a fire-refining operation which gives it the mechanical properties demanded by the metal industries.

In the treatment of my subject I intend to cover the progress which has been made mainly during the last ten years in

I. The smelting of sulphide copper ore in the blast furnace.

2. The smelting of sulphide copper ore in the reverberatory furnace.

3. The conversion of copper matte into crude metallic copper.

4. The fire-refining of crude copper to the market product.

II. SMELTING SULPHIDE COPPER ORE IN THE BLAST FURNACE.

For a great many years all smelteries used the roasting and reduction process. In our days the process is found, on this continent at least, only in a few instances, and the two leading representatives are the Canadian Copper Company and the Mond Nickel Company, near Sudbury, Ontario. As the name of the process indicates, we have to deal with two separate operations.

The first is roasting. This aims to eliminate, by oxidation, all the sulphur in excess of that which is required to furnish the 25 per cent. necessary for the matte to be formed in smelting,

* Presented at the stated meeting of the Institute held Wednesday. October 20, 1915 . 
and to oxidize part of the iron, that it may enter the slag. A blast furnace requires, for good work, coarse ore. The lump ore from the mine which is to be roasted is therefore only broken to pass a 3 -inch ring, and the coarse product then roasted in heaps. A heap is a truncated pyramid of ore not larger than 3 inches in diameter, built onto a bed of wood and covered more or less with fine ore to check the draft. The wood is ignited, kindles the overlying ore, and this burns with a smouldering fire, for weeks or months, the oxidation of the sulphur and iron furnishing the necessary heat. The Canadian Copper Company has heaps 55 by IOO feet and Io to 12 feet high, holding Iooo tons of ore with 20 per cent. S, 40 per cent. $\mathrm{Fe}, 5$ per cent. $\mathrm{CuNi}$, and 24 per cent. gangue. A roast lasts from Io to $\mathrm{I} 2$ weeks; the roasted ore retains Io to I 2 per cent. S.

The second step is smelting. It aims at reduction and fusion. The ore is charged with coke and some flux into a blast furnace; it is subjected to increasing temperatures as it descends in the furnace, and to the two reducing agents $\mathrm{C}$ and $\mathrm{CO}$. The result is that all oxidized copper is reduced and sulphurized, and with it a varying amount of iron; the two sulphides then form the matte. The remaining oxidized iron of the ore is reduced to the ferrous state and combines with the silica of the ore to a ferrous silicate. Other oxides, such as calcium oxide, alumina, etc., also form silicates, and the combined silicates give the waste slags. This formation of copper matte is made possible by the strong affinity copper and iron have for sulphur. So long as there is sulphur in the charge the copper will combine with it to form $\mathrm{Cu} 2 \mathrm{~S}$ and the sulphur still present will be available to form FeS. The difference in specific gravity of matte and slag, 5.5 and 3.5 , allows a good separation so long as the temperature in the earth is high enough to keep matte and slag thoroughly fluid, and a removal from different levels of the hearth.

This roasting and reduction process is expensive and slow, and has had to yield to what is called the pyritic process. This is a blast-furnace process in which the oxidation of raw pyritic ore furnishes all the heat necessary to carry on the operation. An ore to be suited for the process must consist mainly of pyrite or pyrrhotite and uncombined silica. As such ores are scarce, pure pyritic smelting is not common, and partial pyritic smelting has taken its place. In this process the lack of heat caused by the 
unfavorable composition of the ore is made up by the combustion of coke added to the charge.

Pyritic furnaces have been run for days at a time without any carbonaceous fuel whatever; usually, however, 2 to 3 per cent. coke is added to the charge, the carbon of which is oxidized by the sulphur dioxide in the ascending gases near the throat of the furnace and thus warms the charge. In partial pyritic smelting 6 or more per cent. coke is added to the charge, and this coke is burnt by the blast entering at the tuyères. The chemical distinction between pure and partial pyritic smelting lies in the oxidation of the coke; if all of it is oxidized by the sulphur dioxide of the ascending gases near the throat, we have pyritic smelting; if all or most of it is oxidized by the blast, we have partial pyritic smelting.

The chemical analyses of the blast-furnace gases bring out clearly the difference. Gases from pyritic smelting contain $\mathrm{SO}_{2}$ 6 to $8, \mathrm{CO}_{2} 5$ to $\mathrm{I} 6, \mathrm{CO}$ none, free $\mathrm{O}$ none or less than 0.8 per cent. vol.; gases from partial pyritic smelting contain $\mathrm{SO}_{2} 2, \mathrm{CO}_{2}$ up to $\mathrm{I} 4, \mathrm{CO}$ none to 2 , free $\mathrm{O} 8$ to 10 per cent. vol.

The tuyère region of the furnace with pyritic smelting is cool; that with partial work is hot.

The sides of the pyritic furnace become covered above the tuyère region with a bosh consisting of siliceous material of the charge, and this is not the case with partial work.

The slag of pyritic work is usually a singulo-silicate; that of the partial process is much more siliceous.

The best exponent of the pure pyritic process is found in the work done by Sticht at Mount Lyell, Tasmania. The blast furnace, 54 by 210 inches at tuyères and 23 feet 7 inches high, with 24 oblong tuyères, 15 by 3.5 inches, puts through in 24 hours 400 to 500 tons charge containing 2.5 per cent. $\mathrm{Cu}, 25$ to 30 per cent. $\mathrm{S}$, and 3 per cent. coke, with 18,000 cubic feet blast per minute, at a pressure of 64 ounces per square inch. It produces matte with $\mathrm{Cu}_{45}$ to 52 per cent., and slag with $\mathrm{SiO}_{2} 35$ to $38, \mathrm{FeO} 40$ to $48, \mathrm{Ca}(\mathrm{Mg}) \mathrm{O}_{3}$.0 to $3.5, \mathrm{BaO}_{2.0}$ to $3.0, \mathrm{Al}_{2} \mathrm{O}_{3} 0.5$ to 8.3 , and $\mathrm{Cu}$ 0.3 to 0.4 per cent. Thus 95 to 97 per cent. of the sulphur is burnt off and a matte with $\mathrm{Cu} 45$ to 52 per cent. produced from ore with $\mathrm{Cu} 2.5$ per cent., which corresponds to a concentration of 50 into $\mathrm{I}$.

Partial pyritic smelting is the process used almost universally 
in this country and has been brought to a high degree of perfection.

At Great Falls, Mont., the modern copper blast furnace has been evolved by Klepetko. It has been changed in some details, here and there, to meet local requirements, but the original typical form has been retained and has made its way around the world. The furnace, 56 by I 80 inches at tuyères and I 4 feet io inches high, with 26 tuyères 3 inches in diameter, puts through in 24 hours 350 tons charge containing 6.89 per cent. $\mathrm{Cu}, 14.7$ per cent. S, and Io per cent. coke, with I0,500 cubic feet air per minute, at a pressure of 40 ounces per square inch. It produces matte with $5^{\circ}$ per cent. $\mathrm{Cu}$ and slag with $\mathrm{SiO}_{2} 37.7, \mathrm{FeO} 26.2, \mathrm{CaO} 24.4, \mathrm{Al}_{2} \mathrm{O}_{3}$ 8.o, and $\mathrm{Cu} 0.32$ per cent. Thus 78 per cent. of the sulphur is burnt off, and a concentration affected of 7 into $x$.

The striking economic features of the two records are the smelting power (Mount Lyell, 6.8 tons per square foot hearth area in 24 hours, against 5 of Great Falls), and the concentration of ore into matte (Mount Lyell, 50: I, against Great Falls, 7: I), They bring out the favorable character of the ore of Mount Lyell in comparison with the refractory nature of the material treated at Great Falls.

At Anaconda, Mathewson, in 1905, joined two neighboring furnaces, 180 inches or $I_{5}$ feet long, by removing the facing end-walls and filling in the $2 \mathrm{I}$-foot space with a new furnace; he thus obtained a hearth $\mathrm{I} 5+\mathrm{I} 5+2 \mathrm{I}=5 \mathrm{I}$ feet long. This worked so satisfactorily that when another remodelling became necessary in 1906 he erected a furnace 87 feet in length, retaining the standard Great Falls width at tuyères of 56 inches. This monster furnace, 56 by 1044 inches at tuyères and $\mathrm{I} 3$ feet 4 inches high, with I 50 tuyères 4 inches in diameter, puts through in 24 hours I 400 tons charge (or 5.88 tons per square foot hearth area), containing 6.79 per cent. $\mathrm{Cu}$ and $\mathrm{r} 3.80$ per cent. $\mathrm{S}$ and 8.70 per cent. coke, with 52,070 cubic feet air per minute, at a pressure of 40 ounces per square inch. It produces matte with 43 per cent. Cu and slag with $\mathrm{SiO}_{2} 39.3, \mathrm{FeO} 24.2, \mathrm{CaO}_{2} 5.2, \mathrm{Al}_{2} \mathrm{O}_{3}$ 6.2, and $\mathrm{Cu} 0.3$ per cent. There is burnt off 70.58 per cent. of the sulphur, and the concentration is 6.3 into $\mathrm{I}$. The advantages accruing from such a large furnace lie in the saving of labor and of fuel, and in the improvement of the smelting as a whole.

Very few smelteries have enough ore to treat to permit following the example of Anaconda; large-size furnaces erected at 
present are 20 to 30 feet long inside at the tuyère-level; the width ranges from 44 to 56 inches, depending upon the coarseness of the ore. The working height ranges from 13 to 16 feet.

With such large furnaces the preparation of charge, the removal of matte and slag, the supply of air necessary to burn the coke and sulphur, and the recovery and handling of flue dust have shown great improvements over older devices.

In a modern plant the components of the charge are collected in hopper-shaped bins provided with gates and weighing devices and trains of side-discharge cars travelling beneath. These receive the required amounts of ore, flux, and coke, are hauled to the feedfloor on tracks running along the sides of the furnaces, and their contents dumped on one side and then on the other onto deeply inclined cast-iron plates extending from the feed-floor into the furnace. The desired distribution of the furnace materials is attained by allowing the surface of the charge in the furnace to sink more or less before new material is introduced. In this way the ore, flux, and fuel falling from the dumping cars can be delivered near the side or the centre of the furnace.

At the works of the Cananea Consolidated Copper Company, the Tennessee Copper Company, and the Calumet and Arizona Copper Company the Dwight-Messiter ore bedding system has been introduced by means of which ores for the blast or reverberatory furnaces are sampled, bedded, reclaimed, and delivered mechanically to the furnace bins at a cost of 9 cents per ton.

With most furnaces the melted matte and slag flow together from the furnace beneath a tymp, which traps the blast, into a fore-hearth, usually $\mathrm{I} 4$ feet in diameter and 5 feet high, in which the matte separates from the slag. The matte is tapped periodically into ladles which go to the converting department, while the slag overflows continuously either into slag cars to be hauled to the dump, or is granulated by a stream of pressure-water which carries away the granules.

The blast is supplied in most cases by Roots or Connersville rotary pressure blowers. In recent years the turbo-blower is gaining favor, as it delivers a definite amount of air irrespective of the pressure prevailing in the furnace. This is not the case with the rotary pressure blowers.

The gases issuing from the open throat of a blast furnace are cool, $150^{\circ}$ to $250^{\circ} \mathrm{C}$. in a reducing fusion and in true pyritic smeltVoL. I8r, No. $108 \mathrm{r}-7$ 
ing; they are hot in partial pyritic work, $300^{\circ} \mathrm{C}$. and over. With a speed of about 750 feet per minute they carry along with them dust and volatile components of the charge. Most of the dust is readily collected if the gases are sufficiently cooled and their speed retarded to $\mathrm{I}_{5} \mathrm{O}$ feet per minute. The remaining dust and most of the volatile materials used to pass off into the open. Three methods of collecting them have proved economically successful: the Roesing wire system at Great Falls, Mont.; bag-filtration at the Mammoth smelter, Shasta, Cal. ; the Cottrell system of electric condensation is being tried out at Anaconda, Mont., on a large scale.

In the Roesing system, steel wires are suspended in the chamber through which pass the gases. The friction caused between the travelling gases and the stationary wires causes a retardation of the velocity, and with it a settling of the suspended particles. At Great Falls, Mont., Nos. 6 and 8 gauge wires form a horizontal screen, with openings $5 / 8$ inch square, from which are suspended No. Io gauge wires 16 and 20 feet long. The chamber holds I,200,000 wires. It is 348 feet long, I 66 feet wide, and 21 feet high. From the entrance to the chamber, for a distance of $1_{5} 0$ feet, and back from the exit, also for ${ }^{5} 50$ feet, the space is wired; the intervening space is left free from wires. The purpose of this arrangement is to collect dust in the entrance division and fume in the exit division. The arrangement has proved a complete success. The wire system is shaken mechanically from the outside for 30 minutes at intervals of 60 to 90 days to dislodge the adhering dust and fume; this collects in the hoppers of the floor and is gathered.

At the Mammoth smelter, Shasta, Cal., the gases from the blast furnaces are cooled to $100^{\circ} \mathrm{C}$. by drawing with a fan through a series of air-cooled soft-steel pipes, admitting at the same time some air, and then forcing them through a bag-house which contains 3000 suspended woollen bags 34 feet long and 18 inches in diameter. These filter the gases and hold back all solid matter. Furnace gases from pyritic smelting contain $\mathrm{SO}_{2}$ and $\mathrm{SO}_{3}$. The corroding effect of $\mathrm{SO}_{3}$ is neutralized by the Sprague process, in which zinc oxide produced from blende on a Wetherill grate is fed into the gas current; this oxide unites with uncombined $\mathrm{SO}_{3}$ and forms harmless $\mathrm{ZnSO}_{4}$.

The Cottrell process aims to collect dust and fume by having 
a high-potential direct current jump through the cooled gases travelling in the flue, from the needle-points of one pole to the plate-poles of the other. This causes particles of dust and vapor to travel toward the plates with a speed which is proportional to the charges and to the potential gradient between point and plate. This process has proved very effective at Garfield, Utah, for cleaning converter gases. The large-scale experimental work carried on at Anaconda, Mont., is very promising.

The handling of flue dust has shown many improvements.

Briquetting, the old standard method, is falling into disuse. The Tennessee Copper Company pours matte from a ladle over a bed of flue dust. The matte takes up the dust, and the dust furnishes part of the siliceous addition necessary for converting. The Cananea Consolidated Copper Company pours flue dust and liquid converter slag together into a slag-bowl, and this, when filled, is emptied over an inclined slag-dump, where the contents passing downward form lumps suitable for blast-furnace work. The Copper Queen Smeltery, Douglas, Ariz., feeds flue dust and liquid converter slag into a revolving conical cast-iron drum, and discharges the two, intimately mixed, in the form of balls. The Mason Valley Mines Company, near Wabuska, Nev., has in operation two roo-ton Dwight-Lloyd sintering machines in which flue dust with fine sulphides and some coke-fines are blast-roasted to hard cellular cakes.

\section{SMELTING SULPHIDE ORE IN THE REVERBERATORY FURNACE.}

Until about twenty years ago most sulphide copper ores were smelted in the blast furnace; about ten years ago reverberatoryfurnace smelting became quite important; the great improvements made within the past two or three years have made the reverberatory furnace so prominent that, e.g., Anaconda has given up its blast furnaces.

We have seen that the blast furnace requires lump ore if it is to do good work. This lump ore must run high in copper if the operation is to be profitable; but high-grade ores are not abundant, hence the prevailing medium and low-grade ores have to be enriched by ore-dressing work. The enriched product, the concentrate, is a fine-sized material, which is exactly what the reverberatory furnace requires for good work. The losses of copper mineral in ore dressing have been large. The recent advances made 
by flotation methods to treat the slimes produced in ore-dressing have been so successful that the loss in copper mineral has been greatly reduced. There is therefore less hesitation than formerly to enrich ores suited for blast-furnace work by ore-dressing work, and to smelt the entire product of the mine in the reverberatory furnace.

We shall see how the improvements made, in the construction of the reverberatory furnace and the method of handling, in the substitution of oil for grate-burnt bituminous coal, and, lastly, in the use of fuel dust, have caused reverberatory smelting to be cheaper per ton of charge treated in our smelting centres than blast-furnace smelting.

\section{A. Roasting Furnaces.}

The concentrates furnished by the ore-dressing plant contain from 8 to 30 per cent. $\mathrm{Cu}$; they are not rich enough to be smelted direct for a matte with from 40 to 45 per cent. $\mathrm{Cu}$, and have to be rough-roasted to eliminate some sulphur and to oxidize some iron.

Mechanical roasting furnaces are especially suited for the rough-roasting which is to reduce the sulphur content from over 30 to about Io per cent. Montana smelteries have constructed and operated many mechanical roasting furnaces which embodied various principles for moving the ore over the hearths of reverberatory and kiln roasters. Of the great variety of furnaces, the multiple-hearth MacDougall type has outlived all the others. A MacDougall furnace is a vertical cylinder with superimposed horizontal hearths, central rotating shaft with radial stirring arms provided with rabble-teeth set at a proper angle. The ore, fed mechanically at the top, is turned over by the teeth and moved on one hearth from the periphery toward the centre; it drops through a slot onto the next following hearth, is moved there in an opposite direction and drops through slots near the periphery onto the third hearth; it continues to travel in this manner until it is discharged from the bottom hearth into a receiver. The air necessary for oxidation enters through side doors and travels in a direction opposite to that of the ore.

Of the MacDougall type of furnace, three forms are found at copper smelteries: the Evans-Klepetko, the Wedge, and the New Herreshoff.

The Evans-Klepetko furnace is 16 feet in diameter, I 8 feet 
high, has 6 hearths, a water-cooled shaft 9 inches in diameter, and two removable rabble-arms to a hearth. The roasting capacity at Great Falls was 40 tons in 24 hours, the arms making I revolution in 53 seconds; it is 75 tons in 24 hours since the speed of the arms has been increased to $\mathrm{I}$ revolution in 38 seconds. With high-sulphur ores the arms are water-cooled, with lowsulphur ores air-cooled; if there is not enough sulphur present, say under 28 per cent., for the ore roast without extraneous heat, a fireplace is added to deliver a flame to the second or third hearth from the top.

The Wedge furnace is 20 feet in diameter, 22 feet high, and has 7 hearths. The characteristics are: a 4 -foot air-cooled central shaft, for the support of the air- or water-cooled arms, running on roller-bearings, and a furnace top serving as a mechanical dryer. The capacity is roo tons ore in 24 hours with 35 per cent. $\mathrm{S}$ reduced to 7 per cent.; the number of revolutions of the shaft varies with the character of the ore.

The New Herreshoff furnace is 20 feet in diameter, 23 feet high, has 6 roasting and one drying hearths; the central shaft is 18 inches in diameter, carries hollow rabble-arms having vertical partitions extending to near the end. Air forced in at the bottom of the shaft rises, travels outward in one division of a rabble-arm, returns in the other, is delivered to the air-shaft, 3 feet 4 inches in diameter and enclosing the rabble-arm shaft, warmed, and discharged onto the bottom hearth. The capacity is the same as that of the Wedge furnace.

\section{B. Matting Reverberatory Furnaces.}

We have seen that in smelting in the blast furnace $\mathrm{C}$ and $\mathrm{CO}$ generated from the combustion of the coke are the reducing agents; in the reverberatory furnace $S$ is the leading reducing agent; the carbonaceous fuel burned serves only to furnish the heat necessary for the chemical reactions to take place between ore and flux.

In discussing furnace practice I shall confine my remarks mainly to the modern long-hearth furnace with waste-heat boilers, fed semi-continuously, and fired with coal, oil, and fuel dust.

The immediate forerunner of the modern furnace was a furnace with hearth 50 by 20 feet and grate ro feet by 5 feet 4 inches,

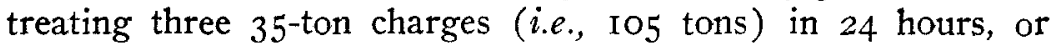


236-pound charge per square foot hearth area, with a fuel ratio of $3: 1$. The charge of hot calcines was dropped from the hoppers in the roof and spread; the side doors were closed and luted, and the fire was urged. When the fusion was completed, the furnace was slightly cooled to stiffen the slag; this was skimmed and part of the matte tapped. Then a new charge was dropped onto the remaining matte and the smelting operation repeated. The new charge cooled the furnace considerably, so that a large part of the eight hours of smelting was taken up to bring the furnace again to a full smelting heat, and then only the remaining part given to smelting proper.

In 1904 Mathewson developed at Anaconda the principle of feeding small charges at short intervals near the fire-bridge of a coal-fired furnace II 2 feet long by 19 feet wide (e.g., I 5 tons charge every 80 minutes and 3000 pounds coal every 40 minutes) ; he skimmed slag every 4 hours, allowed a bath of matte to accumulate to the extent of 200 tons, and grated every 4 hours. Some of the matte was tapped when needed for converting. This method of operating kept the temperature uniformly high. The result was a greater tonnage, a higher fuel ratio, and a longer life of the furnace. The furnace with hearth II 2 by ig feet treated in 24 hours 300 tons charge or 302 pounds charge per square foot hearth area with a fuel ratio of 4.8 : I.

The great advantage of the method of working is striking, and was adopted everywhere.

All reverberatory matting furnaces at present are provided with waste-heat boilers, introduced at Anaconda by Klepetko. The former practice was to burn as little fuel as possible, because the hot gases from a furnace went to waste; with the advent of the waste-heat boiler the practice was reversed, as much fuel as the furnace could stand was burned, and thereby the smelting power greatly increased.

Bituminous coal, run-of-mine or screened, has been the common fuel for the reverberatory furnace. Mathewson has shown that with the best coal available in Montana there was little advantage in increasing the length of a furnace beyond I Io feet, and that Ioo feet is a practical limit.

Oil was used as a fuel at Humboldt, Ariz., in 1906; it was adopted at Cananea, Mexico, in I908; and later at Steptoe, Nev.; Hayden, Ariz.; Garfield, Utah, and at other smelteries. The 
advantages of atomized oil over bituminous coal burned on a grate are important. The calorific power is higher, the feeding is continuous, and the loss of heat from the fire-box-estimated by J. W. Richards at over 25 per cent.-is avoided, as the oil is blown onto the hearth. The result is that the temperature obtained is higher, the smelting power greater (400 against 300 tons in 24 hours), the heat efficiency larger and the amount of the flux needed smaller, as slags with a higher percentage of $\mathrm{SiO} 2,45$ against 40 per cent., can be made on account of the high temperature. The temperature of the furnace at the oil burners is so high that the distance between roof and hearth of furnace has to be large, not less than 6 feet, if the life of the silica roof is not to be abnormally short. On account of the continuous firing and the high temperature, the furnace can be longer than with grate-burned bituminous coal; thus Sörensen put into successful operation at Steptoe, Nev., a furnace with hearth 140 feet long and 19 feet wide in which there were smelted, e.g., from April to July, I9I4, per day, 685 tons charge, or 0.2915 ton per square foot hearth area with a consumption of 0.562 barrel oil per ton.

The feeding of oil through high-pressure atomizer burners is simple and clean in comparison with the supplying of coal to a grate and the time-consuming and exhausting work of cleaning grates.

The latest step in the improvement of fuel supply is the use of fuel dust. This was tried by Sörensen near Salt Lake City in 1906, and by Shelby at Cananea in 1907-08, but was not successful. D. H. Browne, of the Canadian Nickel Company, took up the matter again in 1909 and concluded that the troubles of Sörensen and Shelby were due mainly to stoppage of flues by ashes and to imperfect feeding of dust; the former was overcome by drying the coal to a water-content of I per cent. or less, and by grinding it to a fineness of 95 per cent. passing a roo-mesh screen, the latter by improved apparatus, common with cement kilns in the eastern part of the country. In December, IgI I, a reverberatory furnace fired with fuel dust was put into successful operation. The furnace, II 2 feet long and I9 feet 9 inches wide, has 5 burners, 3 feet 4 inches apart, treats $45^{\circ}$ tons charge in 24 hours with a fuel ratio of $6.77: 1$. In working out the problem, the mode of feeding the ore was changed from the Anaconda manner to dropping the larger part of the charge through 6-inch 
pipes in the roof placed 2 feet apart, and the smaller part through four I I-inch openings near the fire-end. The ore delivered at the sides covered the side walls so that ore was smelted on top of the slag-matte bath and along the sides. The ore is fed at one side all the length of the wall, at the other to the tap-hole placed near the throat. The original hearth of magnesite brick now protected by matte and ore has been replaced by the usual siliceous material.

At Anaconda the Browne method of working has been so successful that fuel-dust firing has replaced grate-firing; the smelting has been so cheapened that blast-furnace work, as stated before, has been stopped. The Anaconda furnace, I 24 feet long by 2 I feet wide, has 5 burners placed 3 feet 3 inches apart, and 6 -inch feed pipes on the sides placed $19 \% / 4$ inches apart for 74 feet from the fire-end; beyond this the furnace requires fettling. The new method of charging has reduced the matte-bath from the original I75 tons to 50 tons. The furnace treats in 24 hours 500 tons charge with a fuel ratio of $7.5: \mathrm{I}$; with grate-firing the smelting power was 260 tons with a fuel ratio of $4: x$.

The latest Anaconda furnace is 147 feet 2 inches long and 25 feet wide; it has Io-inch feed-holes, 24 inches centre to centre; it is expected to treat in 24 hours 800 tons charge with a fuel ratio of $7.7: \mathrm{I}$.

IV. CONVERTING COPPER MATTE.

The conversion of copper matte, first attempted by Raht in I866, at Ducktown, Tenn., and made a practical process by Manhès in I880, forms one of the landmarks in the metallurgy of copper. In the process air in the state of fine division is forced through liquid copper-iron matte held at a temperature of about I $50^{\circ} \mathrm{C}$. in a vessel lined with siliceous material; the $\mathrm{Fe}$ is oxidized to $\mathrm{FeO}$ and simultaneously combines with $\mathrm{SiO}_{2}$ to $\mathrm{Fe}_{2} \mathrm{SiO}_{4}$, while $\mathrm{SO}_{2}$ passes off as a gas. The slag is poured off and the remaining $\mathrm{Cu}_{2} \mathrm{~S}$ blown, with the result that $\mathrm{Cu}_{2} \mathrm{O}$ and $\mathrm{SO}_{2}$ are found, and the $\mathrm{Cu} 2 \mathrm{O}$ as soon as formed acts upon unoxidized $\mathrm{Cu}_{2} \mathrm{~S}$, forming $\mathrm{Cu}$ and $\mathrm{SO}_{2}$. This process was brought to a high degree of perfection in this country, and held its own until I909, when Pierce and Smith, at Baltimore, succeeded in replacing the easily corroded siliceous lining of the converter by the resistant magnesite brick and adding the silica required for slagging oxidized iron by charging siliceous ore. Basic converting has shown so many advantages over the original acid process that it has 
almost entirely replaced the latter. I shall confine my remarks to basic converting.

A characteristic of all matte converters is that they are sideblown, and not bottom-blown, as is the steel converter. There are in operation two classes of vessels, the horizontal and the vertical; typical forms are those of Garfield, Utah, and of Great Falls, Mont.

The Pierce-Smith converter at Garfield is a horizontal cylindrical shell, 26 feet long and Io feet in diameter, supported by three sets of carrying rollers. The shell is lined with magnesite, holds 30 tons copper, has on the blowing side 32 tuyères with I.5inch openings 18 inches above the bottom; at the pouring side there is an opening with spout for introducing the charge and pouring the copper, and at the top is the throat for the passage of the gases into the dust chamber. The cylinder is rotated in a horizontal plane by means of wire ropes.

The Great Falls converter of medium size is an upright cylindrical steel shell, I 2 feet in diameter, and, with hood, I 3 feet 8 inches high, holding $\mathrm{I} 2$ to $\mathrm{I} 4$ tons copper. It has $\mathrm{I}_{5} 2$-inch tuyères $12 \mathrm{I} / 2$ inches above the bottom, and a throat for the receiving of charge, the pouring of slag and metal, and the passage of gases. It is carried by two short trunnion-shafts, attached to friction wheels running on friction rollers, and is rotated in a vertical plane by spur wheel and pinion. This $\mathbf{2} 2$-foot converter has made such an excellent record that it is being introduced at most smelteries. Great Falls and Anaconda now have 2o-foot converters, but most smelteries prefer smaller sizes.

The mode of operating in both vessels is similar. The vessel, suitably prepared and heated, received a certain amount of liquid matte which is followed by a suitable quantity of siliceous ore; it is blown with air at I I to I4 pounds pressure until the iron is oxidized and slagged; the slag formed is then poured. Fresh liquid matte and ore are charged and blown; these operations are repeated once or twice until the vessel is filled with white metal, i.e., practically pure cuprous sulphide with 80 per cent. $\mathrm{Cu}$; the white metal is now blown in the usual way to blister copper to be poured.

The slag formed contains $\mathrm{SiO}_{2} 26$ to $28, \mathrm{FeO} 50$ to 55 , $\mathrm{Al}_{2} \mathrm{O}_{3} 3$ to $4, \mathrm{CaO}$ under I per cent. ; the blister copper about 99 per cent. $\mathrm{Cu}$. 
The Pierce-Smith 26- by I0-foot vessel holds about 40 tons matte; it takes 20 hours to furnish 45 tons blister copper from $45^{-}$ per cent. copper matte, or, roughly, 30 minutes per ton of copper. The Great Falls I 2 -foot vessel holds 12 to I9 tons matte; it takes 4 hours and 20 minutes to furnish I 3 tons of copper, or 20 minutes per ton copper. Thus the work of the upright is quicker than that of the horizontal; the life of the lining is also longer.

The two leading considerations in the operation of the basic converter are the blowing temperature and the $\mathrm{SiO}_{2}$-content of the slag. If the blowing temperature exceeds I $150^{\circ} \mathrm{C}$., the lining is quickly corroded; hence greatest care is taken to keep the temperature down by regulating the blast, by charging cold copperbearing materials, or by allowing slag to accumulate in the vessel, as this retards conversion. The $\mathrm{SiO} 2$-content of the slag is of importance, as a low $\mathrm{SiO}_{2}$ favors the oxidation of $\mathrm{Fe}_{2}$ to $\mathrm{Fe}_{3} \mathrm{O}_{4}$, which adheres to the magnesite lining and protects it, while high $\mathrm{SiO}_{2}$ favors the oxidation of $\mathrm{Fe}$ to $\mathrm{FeO}$, which enters the slag and favors corrosion of the lining.

\section{FIRE REFINING OF COPPER.}

The aim of the process is to remove from metallic copper foreign substances which impair its physical properties. As practically all the copper received by our refineries is converter metal with about 99 per cent. $\mathrm{Cu}$, and cathode metal, which is still purer, the chemical aspect of the process is comparatively simple.

The researches of Wanjukow and Stahl have thrown new light upon this question. They conclude that (I) $\mathrm{Zn}, \mathrm{Fe}, \mathrm{Co}$, and $\mathrm{Sn}$ are completely removed at the beginning of the oxidizing stage, and $S$ at the reducing or poling stage; (2) that the elimination of $\mathrm{Ni}, \mathrm{Pb}, \mathrm{As}$, and $\mathrm{Sb}$ continues through the entire process and imperfect; and (3) that $\mathrm{Ag}$ and $\mathrm{Bi}$ are removed only to a very small extent.

The operation is carried on in a reverberatory furnace. It involves (I) charging, (2) melting, (3) partial oxidation of the fused metal in order that the $\mathrm{Cu} 2 \mathrm{O}$ formed, which is soluble in copper and has a smaller affinity for $O$ than the foreign substances removable by fire, may oxidize the impurities and cause them to rise to the surface to be skimmed, and (4) reduction of the $\mathrm{Cu} 2 \mathrm{O}$ by poling to give the metal the required degree of malleability and ductility. 
The improvements made in the process are mainly mechanical. Formerly the metallic copper was charged by hand and the refined copper ladled. This limited the size of a furnace; through one door 8 tons of metal can be charged per hour; the use of pneumatic lifts increases this amount to 17 to 20 tons. The mechanical chargers of Prosser and Ladd, and Clarke-Antisell handle I 50 tons cathodes in 2 hours with 2 men.

Ladling the copper from a 25 -ton furnace into ingots weighing on the average 17 pounds takes about 4 hours; ladling with a trolley-supported ladle permits casting twice the amount in the same time. This is about the limit. Furnaces used to hold I 5 tons copper, later their capacity was increased to 40 and 50 tons, but this was the limit until A. R. Walker constructed his casting machine, which handles as much as 400 tons copper in less time than is necessary to cast 40 tons with a trolley-supported ladle. With mechanical charging and mechanical casting the size of the charge to-day is governed solely by the ability to construct a furnace, especially a furnace bottom, which will stand such enormous weights, and by the skill of the refiner in holding such a bath of copper at the desired pitch; i.e., that the copper shall not be over- or under-oxidized. Modern furnaces hold from 80 to 400 (usually 200 to 250 ) tons copper, starting with cathodes, and finishing with ingot, wire bar, and cake copper.

[A number of lantern slides of copper plants, roasting and reverberatory furnaces, converters and other machinery were showr and described during the course of the lecture.]

Locked-up Potash. (Overland Guidebook, Bulletin No. 6i2, U. S. Geological Survey.) -About two miles northeast of Superior, Wyo., are the Leucite Hills, which are made up largely of igneous rocks in the form of volcanic necks, sheets intruded into the stratified rocks, and dikes cutting across the sedimentary strata. Associated with these intrusive rocks are volcanic cones and lava flows. These rocks have long been objects of scientific interest because of their unusual character. Lately they have attracted additional interest by reason of the potash-rich mineral, leucite, they contain, which may some day be utilized if a process can be found for extracting the potash cheaply. It has been estimated that the igneous rock of the Leucite Hills contains more than I97,000,000 tons of potash. 